\title{
Submit or Resist: Google, is there a third way? Deborah Hicks
}

\begin{abstract}
This article explores the impact that Google is having on the library profession. Google is enticing users away from their local libraries with its siren song of easy use and "good enough" results, and librarians are struggling to come to terms with the loss of users. In response, the library community has divided itself into two "sides": those who want librarians to "submit" to the search capabilities of Google (the Googleizers) and those who want librarians to return to the profession's traditional role of information gatekeeping. This paper proposes that there is a potential revolutionary third option for librarianship: the librarian as an activist for the right to communicate.
\end{abstract}

\footnotetext{
About the Author(s): Deborah Hicks is currently a student at Dalhousie University's School of Information Management. She grew up in Halifax, Nova Scotia and completed a Bachelor of Arts with Combined Honours in History and Contemporary Studies at The University of King's College (Halifax). She completed a Master's of Arts in History at York University in Toronto. This paper was originally written for Information and Society, a first year class in the School of Information Management's programme. In this class, Deborah heard Dr. William Birdsall speak about the right to communicate and it inspired her to write this paper.
} 


\section{Introduction}

"But if we don't assert the importance of that role, of the centrality of selecting, acquiring, retaining, preserving and building means of access to collections, we will inevitably fade away." -Michael A. Keller, Victoria A. Reich and Andrew C. Herkovic, from "What is a library anymore, anyway?"

"Sixty-five million years ago the Age of Reptiles came to a cataclysmic extinction known as The Great Dying. There is still controversy over what happened, but all theories agree that the dinosaurs died out because the environment changed and they couldn't adapt. Librarians are well positioned to thrive. But the future is not what it used to be. Our expertise is no longer an extension of the past. Looking into the future is like looking into a kaleidoscope: everything is constantly changing, quickly. We have evolved many times over the history of Libraryland. We can do it again." -Stephen Abram, "The Google Opportunity"

Libraries and librarianship faced a great change from 1886 to 1919 when Andrew Carnegie donated $\$ 56$ million to construct libraries in both Canada and the United States of America. According to Richard E. Rubin in Foundations of Library and Information Science, Carnegie's funds were directed specifically toward the library buildings, not the collections housed in them, leaving the local librarians to stock the shelves with materials of local interest. This had such an impact that "the specifically local character of today's public library collections and services may be a direct result of the special conditions and restrictions that Carnegie required of every donation" (Rubin, 2004, p. 290). Currently, libraries and librarianship are facing a new change: digitization. With the creation of the Internet, libraries and librarians have been forced to come to terms with a shift from local collection development, as set forth with the help of Andrew Carnegie, to online resources being available to anyone, anytime. Nothing has brought this dichotomy into the light like the search engine Google. This paper will look at the debate surrounding Google in library science literature, as characterized by the two quotations above. Librarians are "taking sides" in this debate. One side is demanding that librarians "submit" to the searching capabilities of Google (the Googleizers) while the other side is demanding that librarians "resist" the siren song of Google and return to librarianship's traditional role of information gatekeepers (Resistors). However, what is missing from this debate is a strong voice calling for a revolutionary change in the profession, for a true re-examination of core values, not just a renewing of values. This paper will look at a possible third way for modern librarianship: librarians as activists for the right to communicate.

\section{Librarians and Google}

The debate over Google in the library community started to heat up last December when Google announced that it was planning to digitally scan books from five major libraries, allowing Google users to search them online. According to Google: 
The Library Project's aim is simple: make it easier for people to find relevant books specifically books they wouldn't find any other way such as those that are out of print while carefully respecting authors' and publishers' copyrights. Our ultimate goal is to work with publishers and libraries to create a comprehensive, searchable, virtual card catalog of all books in all languages that helps users discover new books and publishers discover new readers. (Google Book Search, 2005)

Google has made searching Google Book Search (as it is now known) as simple as searching its main search engine, Google.com. The user performs a simple keyword search and Google returns the content that best matches the query. Unlike a library, Google offers its users the opportunity to buy the selected book as well as find it in a local library. Although, the commercial nature of the project is concerning to most librarians, the substance of the debate is focused on the keyword search capabilities of Google itself.

Google relies on software called PageRank to determine the position of a search result. As Google explains it:

PageRank relies on the uniquely democratic nature of the web by using its vast link structure as an indicator of an individual page's value. In essence, Google interprets a link from page A to page B as a vote, by page A, for page B. But, Google looks at more than the sheer volume of votes, or links a page receives; it also analyzes the page that casts the vote. Votes cast by pages that are themselves "important" weigh more heavily and help to make other pages "important". (Google Technology, 2005)

This, combined with keyword searching, which Google claims is content sensitive (Google Technology, 2005), allows Google to find thousands, and sometimes millions, of sites for each individual search. The relative ease of searching Google has encouraged many library users to bypass the reference desk and head straight to Google whenever they have an information query. However, many librarians are wary of Google's keyword searching capabilities. In a recent American Libraries article, Thomas Mann gave a scathing critique of Google's keyword searches. He claims that PageRank cannot sort the "wheat" from the "chaff" because relevant information might not be the most "popular" information. If information is obscure, then Google's PageRank software ends up hiding it. In addition, he claims that Google can only manipulate results within a keyword search, and is unable to "build bridges among multiple sets using different words for the same idea, or covering different aspects of the same subject" (Mann, 2005, p. 46). He further claims that Google is in fact incapable of context sensitivity, making Google's keyword searching the destroyer of systematic subject searching in research collections (Mann, 2005).

Not all librarians have such negative feeling towards Google. Some see Google as an opportunity to adapt the profession. Stephen Abram, in "The Google Opportunity" suggests ten things that a library can do to adapt to a "Google world" (Abram, 2005). He believes that 
"Google has staked out an extremely strong position in the mind of the information seeker," and therefore, librarians must adapt and respond if they "value their communities" (Abram, 2005 , p. 35). His suggestions range from improving users' information literacy, to rethinking the library as a repository for texts by getting involved with Internet archives, to pushing new content onto users so that they can become aware of it. He places a lot of emphasis on ensuring that libraries remain in the community by moving traditional library services, like collection development, into an online environment.

\section{Resist or submit? Googleizers vs. Resistors}

The debate between the Googleizers and the Resistors (as they have called themselves) is characterized by its "either/or" dichotomy. Two examples of this debate are found in Library Journal, where a transcript of a live debate was placed, and American Libraries, where a transcript of an e-mail symposium can be found. These debates involved eight participants, who can be divided into two equal groups landing firmly on opposite sides of the Google debate. At the core of these debates are the values of librarianship. Originally set forth by S.R. Ranganathan, library values can be condensed into five laws:

Books are for use.

Books are for all; or, Every reader his [or her] book.

Every book its reader.

Save the time of the reader.

A library is a growing organism (Ranganathan, 1957, p. 9).

The importance of these five laws to librarianship cannot be underestimated. In 1998, Michael Gorman called these laws "an intellectual framework for understanding all aspects of library work" (Gorman, 1998, p. 22). They underlie the service ethic of librarianship: "Libraries are about service or they are about nothing. In everything we do, from an individual act of assistance to a library user to our collective efforts to support education and preserve knowledge for posterity, we are animated by the will to serve" (Gorman, p. 22).

In 1995, Michael Gorman reinterpreted these laws for the modern library. His new laws do not replace Ranganathan's laws. Instead, they build upon them, so that they are applicable to a Googlized world. Gorman argues that his laws allow librarians to keep the old values of librarianship, as outlined by Ranganathan, while making room for new technologies like Google. Gorman's new laws are: 1) Libraries serve humanity. Gorman noted that service, or "individual acts of help and the furtherance of the higher aspirations of humankind," was the dominant ethic of librarianship. 2) Respect all forms by which knowledge is communicated. This is an acknowledgement that libraries will house all kinds of knowledge and information in the future. 3) Use technology intelligently to enhance service. Librarians do not have to choose 
between being a Luddite or a "soulless technocrat." A balance can be found. 4) Protect free access to knowledge. Gorman argues that allowing records of the past to disappear is a form of censorship and that libraries, as centres for social, political and intellectual freedom, must preserve all records and make them available to all. 5) Honour the past and create the future. Libraries must retain a sense of the past so that they can continue with their missions to provide free access to all information. At the same time innovation must be embraced: "Libraries need to combine the past and the future in a rational, clear-headed, unsentimental manner" (Gorman, 1995, p. 785).

Primarily, the self-proclaimed Resistors appeal to the professional values of their readers. Steven Bell, one of the "Resistors," challenges librarians to retain their traditional values in his article "Don't Surrender Library Values." He implies that librarians who follow the new Google world order will do a disservice to their patrons by reducing the complexity of a traditional library search into the simplicity of a Google search, and as a result, missing the best possible sources (Bell, 2005). Bell wants librarians to create information-wise consumers, or at the very least to put users on an "infodiet":

Think of the library as the carving station that's been abandoned while the diners line up for greasy burgers and fries. Too many students are bringing a "supersize it" mentality to research, in effect asking librarians, "Can you Google-ize that for me?" ... [The] outcome of Google-izing research: a junk-information diet, consisting of overwhelming amounts of low-quality material that is hard to digest and leads to research papers of equally low quality. (Bell, 2004, p. B15)

Other Resistors worry about the loss of face-to-face contact with patrons, blaming the rows of hunched-over computer users on the changing value systems of librarians. In "Second Thoughts on the Paperless Society," F.W. Lancaster states that "today it seems more important to have knowledge of new databases, new search engines, new word processing systems, new communications protocols, and new gizmos than to know or have concern for our communities of users" (Lancaster, 1999, p. 51).

The Googleizers herald the user-customized services and collections that Google offers, along with the expanded access to information that Google represents. They claim that the profession used to be about the selection and control of information, but that now it is "about finding." Or, as Judy Luther, one of the "Googleizers," states: "Gone is the era where [librarians] are the gatekeepers, when we stand between our users and their access to information" (Kenney, 2004, p. 45). In "Google at the Gate," they even caution against relying too much on traditional library values:

to equate the value proposition for libraries with their purchased collections is akin to assessing an educational experience solely on the basis of the textbook used. ... Every library collection is wrapped in services, and both the services and the collections reflect 
the unique needs and interests of the library's community of readers and learners. Smart libraries will continue to take advantage of any and all opportunities to improve access to resources and service to their communities. (Flagg, 2005, p. 44)

Resistors all share the common theme of praising traditional library values and skills as the only way to forge a place for librarianship in the future. Googleizers, on the other hand, say that if librarians do not adapt to the new Google world order, the profession will be left behind, wondering what went wrong. However, other than saying that "good enough is good enough" (Kenney, 2004, p. 46), they offer very few concrete and innovative paths for the profession's future. Most Googleizers believe that by simply increasing access to information, they will have done their jobs. A few advocate the adaptation of traditional library values for the digital arena (Abram, 2005, for example), offering a middle ground between total acceptance of Google and total resistance, but these adaptations do not resolve the central dichotomy of the Google debate: do librarians submit to or resist the siren song of Google?

\section{The Future}

Librarians have been speculating about the future of the profession for many years. The Internet and "cyberspace" have had a big impact on those speculations. One of the more common threads of thought is the complete disappearance of the library as a physical institution:

Librarians or the competence of librarians, transformed into something slightly different or nearly similar, in the future will be of interest to all kinds of information or knowledge industries and activities - private or public. However, the institution or department which is called the "library" can look to a much more insecure future. (Bakken, 1998, p. 82)

One of the more extreme and intentionally puzzling views of the future is put forth by Charles Martell in his two-part essay "The Disembodied Librarian in the Digital Age." He calls for a revolutionary, not evolutionary, change in the library profession: "The common view among librarians is that the changes in their profession are following an evolutionary, rather than a revolutionary, pattern. From this perspective, relatively few adaptations will be required of them. However, this vision is too narrow" (Martell, 2000a, p. 12). Martell believes that the digital age will completely alter what it means to be human, both conceptually and consciously. He sees this change coming in the dichotomies between time and space, mind and body, real and virtual, and humans and technology.

His writing is heavily influenced by William Gibson's use of the term "cyberspace" in his 1984 novel Neuromancer:

Gibson's vision is bold. His metaphor is powerful. It dwarfs our common perceptions of the Internet. His understanding of cyberspace was formed by reading reports from MIT computer labs and watching kids playing video games at the arcades on Granville 
Street in Vancouver. "These kids clearly believed in the space these games projected". (Martell, 2000a, p. 15)

In Martell's view, cyberspace has huge implications for the library profession. Gone are the days when the physical building was the centre of the library. In the digital age, the virtual space created in cyberspace by librarians will become central. All library services will be virtual, making current service philosophies marginal. Librarians will have to move from a value-neutral approach to service, to a value-added approach (Martell, 2000b).

Martell believes that his approach to future librarianship is revolutionary. However, it ultimately sounds very much like the Googleizers' approach to modern librarianship. He believes that keyword searching will make the traditional controlled-vocabulary search irrelevant, although "whether users will be more successful in retrieving relevant information as a result of these changes is unclear" (Martell, 2000b, p. 105). However, like the Googleizers, he is not overly concerned with the quality of the information gathered, but rather the user's ability to access information. He sees three trends conspiring to make access the central issue in librarianship: 1) the erosion of funding to libraries, 2) the rapid growth of electronic information, and 3) the increasing utility of this information for teaching and research. As librarians provide access to electronic information, they will free themselves from the physical world of the library, and start to enter into the disembodied world of cyberspace (Martell, 2000b). And, he cautions that "if librarians are unable to find comfortable roles in cyberspace with new value-added products and services, it will be difficult to maintain the relevance of librarianship as it exists today" (Martell, 2000b, p. 111).

What are these "value-added" services? According to Martell, librarians in the future must anticipate the needs of their users by compiling user profiles and use information. This valueadded librarianship actually tramples on one of the core values of modern librarianship: the right of users to have their privacy protected [1]. Is this trampling truly as revolutionary as Martell hopes? No. Instead of revolutionizing the profession, Martell simply adds fuel to the Googleizer and Resistor dichotomy, for he proves to the Resistors that succumbing to the siren song of digitization and Google will only erode, and eventually destroy, the profession.

\section{The Right to Communicate: A possible third way}

Is the debate over the future of librarianship destined to be stuck in a Googleizer vs. Resistor stalemate? Is there a possible Third Way? The middle ground offered by Stephen Abram is certainly a tantalizing option, for he seemingly offers a way for librarians to have their digital cake and eat it too. If librarians are to heed Martell's call to real revolutionary action, then another option must be considered: the librarian as an advocate for communication rights. The framework for the right to communicate for this paper will be based on the article "The Internet and the Right to Communicate" by William J. Melver Jr., William F. Birdsall and Merrilee Rasmussen. In the article, the authors state that: 
The development of the Internet challenges traditional conceptions of information rights including freedom of speech, copyright, universal access, cultural, lingual, and minority diversity, and privacy. The discourse surrounding these rights typically deals with each in isolation. As well, these discussions strive to adapt long established understandings of each right to the new technological environment. (Melver, Birdsall, and Rasmussen, 2003)

They believe that the only way to properly address the challenges of the Internet is to address the needs of information freedoms with the human-rights framework of the right to communicate. For Melver, Birdsall and Rasmussen, "the ability to communicate is the essence of being human"; consequently, the right to communicate is a basic human right.

The right to communicate has its roots in the United Nations Declaration of Human Rights:

Everyone has the right to freedom of opinion and expression; this right includes freedom to hold opinions without interference and to seek, receive and impart information and ideas through any media and regardless of frontiers.

(1) Everyone has the right freely to participate in the cultural life of the community, to enjoy the arts and to share in scientific advancement and its benefits. (2) Everyone has the right to the protection of the moral and material interests resulting from any scientific, literary or artistic production of which he is the author.

Everyone is entitled to a social and international order in which the rights and freedoms set forth in this Declaration can be fully realized (United Nations, 1998).

These articles are, however, unable to cover the rapid change in communications brought forth by satellites and the Internet. For example, Article 19 is only concerned with the "free flow of information or content rather than ... the process of communication" (Melver et al., 2003). For Melver, Birdsall and Rasmussen, this narrow scope excludes the possibility of horizontal and interactive communication. This concern is based upon Jean d'Arcy's concept of "mass media mentality," which is the acceptance as "normal and ineluctable a unilateral, vertical flow of nondiversified information" (Melver et al., 2003); in other words, the acceptance of a one-way content distribution through broadcast media. The emergence of communication tools, such as the Internet, challenges this vertical communication flow by allowing "communication interactivity," which demands a rethinking of "patterns in terms of the era of ... the computer ... rather than to attempt to force tomorrow's tools into today's structures" (Melver et al., 2003).

The right to communicate is inherently difficult to define because it simultaneously encompasses traditional rights and freedoms, which occasionally conflict with each other (for example the rights to freedom of expression and privacy might conflict with property rights), while attempting to create an entirely new human right. There have been many debates over the content of the right to communicate; however, none of them has resulted in concrete 
agreement between all involved parties. What has emerged is a framework for future actions where "the right to communicate, in contrast to traditional freedoms of one-way communication, would embody a conception of participatory, interactive, horizontal, and multiway communication" (Melver et al., 2003).

What separates the right to communicate from both the Googleizers and the Resistors is its attempt to rethink communication. Both the Googleizers and the Resistors seem content to "force tomorrow's tools into today's structures" (Melver et al., 2003). On the one hand, the Googleizers want to simply allow access to the content of the Internet. They do not take the next conceptual step of dealing with the complex issues that the Internet poses: intellectual freedom, property rights, cultural and linguistic rights, and privacy. These problems are ignored when the focus is solely on access to information and content.

The Resistors, on the other hand, are content to cloak themselves with potentially outmoded professional values and ethics. Let us return to the core values of librarianship as originally set forth by S.R. Ranganathan, and Michael Gorman's five additions, to see if these core values are outmoded. Values one, two, and three are primarily focused upon the content of a book (or other information packages), rather than the process of communication. Books, and other traditional information packages, communicate their knowledge in a vertical and non-diversified way. One cannot directly communicate back to a book, journal article, or CD, for example, even if that object has found its audience, and vice versa. The fourth value simply addresses the accessibility of vertical information. The values that come closest to addressing the concerns of Melver et al. are values five through ten. Each of these values begins to address the concept of communication. However, all, except for value five, still place the librarian in the position of information gatekeeper, not communications advocate. Excluding value five, to be discussed shortly, nine of the core values of librarianship are concerned with the vertical and unilateral dissemination of non-diversified information.

Value five, "a library is a growing organism," allows room for the right to communicate in modern librarianship. If the concept of library is taken to mean more than simply a physical building, then this value can eclipse the other nine to make room for a new set of values based on the right to communicate. Concern about the future of the physical library is what fuels much of the Resistors' defiance of the realities of the Internet. In "What is a Library Anymore, Anyway?," Keller, Reich, and Herkovic (2003) worry that once the local content of the library is replaced with the global content of the Internet, the library, as it is currently conceived, will cease to exist. They want librarians to continue to be information gatekeepers: "[We] need to be deliberate about what we gather, control carefully what we do gather, and even more deliberate about discarding information" (Keller, Reich, and Herkovic, 2003). How then do librarians move from being information gatekeepers to communications advocates?

During a lecture on October 26, 2005, William F. Birdsall discussed his belief that librarianship would become the paradigm profession of the Twenty-first Century. He stated that the 
traditional values of librarianship were no longer enough to sustain the profession because they were based on the concept of an informed citizen exercising his or her democratic rights with information supplied by government and the broadcast media. Birdsall believes that the concept of an informed citizen should be replaced with the concept of a communicative citizen, or a citizen who is active in the communicative process of democracy, and not a passive recipient of information and content. The library, both as a physical place and as a concept, is the perfect social institution for people to exercise their right to communicate. The primary resource of the library would cease to be the books and other information packages, and become the staff. He outlined three steps that librarians should take to become communications advocates:

Librarians should help to develop the definition of right to communicate;

Librarians must re-examine their values under the view of the right to communicate;

Librarians must take the lead as advocates for the right to communicate.

Birdsall's three steps will be difficult for librarians to take. As the arguments reviewed in this paper show, the future is hotly debated. Perhaps Birdsall is a little optimistic in his first step. Instead, perhaps the first step should be for librarians to stop arguing over topics like keyword searches versus controlled vocabularies, and the effect that Google is having on libraries and their patrons. What both sides of the Google debate share is a deep concern for the future of the profession. If the profession is to have a future, it must start to look at alternatives to the current debate. It must open itself up to all future possibilities and remember why Ranganathan wrote his Five Laws of Librarianship: to serve the library patron. The right to communicate offers librarians a new way of serving their patrons; a way that is not concerned with divisive debates over searching terminologies and Internet search engines.

\section{Conclusion}

The right to communicate will not resolve all of the concerns that Google poses to the profession. It may indeed create, or at least fuel, concerns over ownership of the media and telecommunications industries. Melver et al. are understandably concerned about corporate media dominance, which reduces "the ability of citizens to seek, receive, and impart information." It is well known that Google's PageRank software does miss much of the information that exists on the Internet, and, if Google's user domination is to continue, valuable communication opportunities might be missed. This, however, is an opportunity for librarians to demonstrate that they are the library's greatest resource. Instead of either submitting to, or opposing, Google, librarians should use their skills to show users their communications alternatives. That would be a first, if small, step in moving toward a profession based on advocacy, not gatekeeping. 
The question of how librarians can become communications advocates, and not information gatekeepers, is not easily resolved. The core values of the profession must be re-evaluated this will cause great discomfort and a lot of debate. It requires that librarians re-examine the profession with an eye to real-world solutions and not science-fiction fantasies. Martell was right: we do need a revolution. Librarians must resist the urge to further divide the profession into Googleizers and Resistors. They must instead re-examine their core values so that even if the future is a "kaleidoscope" of constant change, we are able to adapt to the change, and not force those changes to adapt for us.

For two examples of Library Association position statements regarding privacy please go to

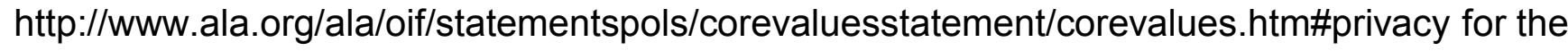
American Library Association's statement and http://www.cla.ca/about/ethics.htm for the Canadian Library Association's statement. Specifically Articles 19, 27, and 28.

For a more complete discussion of the struggle to define the right to communicate please refer to the section "UNESCO and the right to communicate" in "The Internet and the Right to Communicate" by Melver et al. 


\section{References}

Stephen Abram, 2005. "The Google Opportunity," Library Journal, volume 130, number 2 (1 February), pp. 34-35.

Frode Bakken, 1998. "The Possible Role of Libraries in the Digital Future," Libri, volume 48, number 2, pp. 81-87

Steven Bell, 2004. "The Infodiet: How Libraries Can Offer an Appetizing Alternative to Google," The Chronicle of Higher Education, volume 50, number 24 (20 February), pp. B15.

Steven Bell, 2005. "Don't Surrender Library Values," Library Journal, volume 130, number 9 , (15 May), pp. 79.

Gordon Flagg, 2005. "Google at the Gate," American Libraries, volume 36, number 3 (March), pp. 40-44.

Google Book Search Library Project at http://books.google.com/googlebooks/library.html</a>, accessed 28 November, 2005.

Google Technology at http://www.google.com/technology, accessed 28 November, 2005.

Michael Gorman, 1995. "Five New Laws of Librarianship," American Libraries, volume 26, number 8 (September), pp. 784-785.

Michael Gorman, 1998. "Five Laws of Library Science: Then and Now," School Library Journal, volume 44, number 7 (July), pp. 20-24.

Mark Y.Herring, 2005. "Don't Get Goggle-Eyed Over Google's Plan to Digitize” The Chronicle of Higher Education, volume 51, number 27 (11 March), pp. B20

Michael A. Keller, Victoria A. Reich, and Andrew C. Herkovic, 2003. "What is a library anymore, anyway?" First Monday, volume 8, number 5 (May), at http://www.firstmonday.org/issues/issue8_5/keller/index.html, accessed 28 November, 2005.

Brian Kenney, 2004. "Googleizers vs. Resistors," Library Journal, volume 129, number 20 (December), pp. 44-46.

F.W. Lancaster, 1999. "Second Thoughts of the Paperless Society," Library Journal, volume 124, number 15 (15 September), pp. 48-50.

Thomas Mann, 2005. "Google Print vs. Onsite Collections," American Libraries, volume 36, number 7 (August), pp. 45-46.

Charles Martell, 2000. "The Disembodied Librarian in the Digital Age," College and Research Libraries, volume 61, number 1 (January), pp. 10-25. 
Charles Martell, 2000. "The Disembodied Librarian in the Digital Age, Part II," College and Research Libraries, volume 61, number 2 (March), pp. 99-113.

William J. Mclver, Jr., William F. Birdsall, and Merrilee Rasmussen, 2003. "The Internet and the Right to Communicate," volume 8, number 12 (December), at http://www.firstmonday.org/issues/issue8_12/mciver/index.html, accessed 30 November, 2005.

S.R. Ranganathan, 1957. The Five Laws of Library Science (2nd ed.). London: Blunt and Sons, Ltd.

R.E. Rubin, 2004. Foundations of library and information science (2nd ed.). New York: NealSchuman Publishers, Inc.

United Nations "All human rights of all: Fiftieth anniversary of the Universal Declaration of Human Rights, 1948-1998: Universal Declaration of Human Rights," at http://www.un.org/Overview/rights.html, accessed 30 November, 2005. 